$\xi=-1$

\title{
A Review of Key Factors That Affect University Building Maintenance Costs
}

\author{
Prescilla Palis $^{1}$, Mohd Saidin Misnan ${ }^{2}$ \\ ${ }^{1,2}$ Department of Quantity Surveying, Faculty of Built Environment, Universiti Teknologi Malaysia, \\ 81310 Skudai, Johor Bahru, Johor, Malaysia \\ *Corresponding author E-mail: prescilla2@live.utm.my
}

\begin{abstract}
As Malaysia continues to focus its efforts on becoming an education hub, universities are vital places where learning processes, teaching and research activities are conducted. A university is a factor of production in producing graduates, and the university buildings are considered to be assets and resources. Hence, to prolong a university building lifecycle to ensure all university activities continue performing at an optimum level, building maintenance management is vital. Despite the fact that several previous studies have been conducted in this area, there continues to be maintenance issues surrounding university buildings. The maintenance of university buildings has always been viewed as an insignificant activity. Therefore, the objective of this paper was to critically review key factors that affected maintenance costs of university buildings, and consequently propose different approaches to resolve this issue. The present paper reviewed related literature from previous studies and publications. As a result of the comprehensive review, it was identified that key factors that affected university building maintenance costs were fund allocations allocated by university management teams for maintenance departments, user behaviours, environmental factors, university design complexities and the quality of components and materials of university buildings. Each factor identified was critically examined and addressed to ensure that university buildings would be well-maintained.
\end{abstract}

Keywords: University Buildings; Maintenance Management; Key Factors; Maintenance Approaches

\section{Introduction}

It is undeniable that universities assist Malaysia to develop by progressing the intellectual culture of its people towards a workability attitude. In addition to this, the government also expects universities to contribute to Malaysia's high-income status and play an important role in propelling innovation in Malaysia, which can assist it to become a high-income economy. In order for Malaysia to become a developed nation by the year 2020, there needs to be experts that can contribute to the sustainable development of the country. Therefore, universities play an important role, as their primary function are places of study that will mainly produce graduate experts in every field. The graduate experts can compete in the future for a better nation $[1,2]$.

University buildings can be considered as assets and resources, whereas a university itself is a main factor of production to produce graduates. The primary purpose of universities and the processes associated with those purposes will run smoothly if university buildings are in excellent condition and have practical qualities. The reason for this is, it can create a better environment, provide comfort, as well as promote values in the minds of building users. Thus, maintenance management of university buildings should be considered to add value, rather than solely be a responsibility. Furthermore, every university building's value depends on the quality of maintenance work that has been carried out [3].

Despite the fact that several previous studies have focused on university building maintenance issues, university maintenance issues are still prominent. The reason behind this problem is, maintenance is seen as an insignificant activity. Moreover, [4] asserted that university maintenance issues occurred due to insufficient or minimal building maintenance management knowledge. The lack of knowledge stems from the fact that the issue is not given high priority or is neglected. The above finding has been supported by [5], who stated that experimental studies discovered that Malaysian university buildings have not been well maintained and caused the dissatisfaction of building users with building conditions and performance.

The dissatisfaction causes the users of university buildings to become more apprehensive about a building's performance. Consequently, many complaints and criticisms are made which relate to the performance of university buildings. As time goes on, university buildings start to age, decay, deteriorate and fail. Moreover, as buildings begin ageing, building maintenance costs often promptly increase [6]. Hence, proper implementation of maintenance management practices should be taken to extend building life spans and to avoid unnecessary failures of building elements.

Furthermore, it is crucial to ensure that university buildings are always in excellent condition and maintained well, to operate efficiently from day to day. Indeed, if university buildings are well-maintained, there is no doubt that they will provide a suitable environment for building users. Thus, the objective of this paper was to critically review key factors that affected maintenance costs of university buildings, to enable the author to propose different approaches to tackle this issue. 


\section{An Overview of University Building}

University buildings are simple, reasonably unsophisticated, static and much more extensive in scale compared to cars, computers and most other products. University buildings act as an envelope which buffer external environments and create an internal atmosphere which supports domestic needs. Therefore, university buildings are not just bricks and mortar, but are more likely seen as skin which surrounds its occupants and modifies the conditions of an environment [7]

[8] stated that university buildings can be likened to living organisms that need to be understood, nurtured and possibly developed. In addition to this, [9] also expressed the idea that university buildings are living organisms. Moreover, they hypothesized that university buildings even go through fundamental stages in natural birth cycles such as growth, maturity, decline, decay, death and rebirth. Thus, university buildings require maintenance to keep the university building cycle under control, similar to all living organisms.

The definition of a building defined by [2] advocated that university buildings should be made up of walls, a roof and other components. [10] confirmed that university buildings were indeed made up of layers or parts. [11] was of the view that university buildings were made up of four layers, which was a shell, services, a scenery and a set. On the other hand, [2] suggested that university buildings consisted of three major components, which were a structure, a building element and building services, for example, mechanical and electrical elements.

\section{The Importance of University Building}

The importance of university buildings should not be underestimated. According to [7], university buildings are a primary physical asset of an institution in terms of both size and cost. Indeed, the main function of university buildings are to provide shelter and facilities for education activities, work and leisure. Therefore, university buildings are a valuable asset to an institution. [12] shared that university buildings assist with providing an essential indoor atmosphere that is comfortable, safe and creates a conducive environment to carry out further activities in the long term.

Undoubtedly, university buildings play a significant role in sustaining and enhancing the core business of any education institution. Despite their important role, university buildings were and still are, perceived as expensive overheads. Furthermore, in some cases they are regarded as a liability. University buildings are also recognized as a commonplace, rather than an essential facility. As a result, their value and functions are often ignored [13]. In recent years, the perception of university buildings is changing. Nevertheless, [5] and [14] expressed the view that there is still a danger of underestimating or overlooking the significance of university buildings as an essential resource.

[15] stated that the functions of university buildings are to protect building users and equipment from natural elements such as sun and rain, and provide an interior space. Moreover, university buildings should be conducive environments that are suitable for educational activities to take place and should provide infrastructure and services that are necessary to help carry out activities.

Buildings are not acquired for their own sake. Instead, buildings are procured to satisfy the needs of its users. The purpose of university buildings are to provide shelter for academic activities that could otherwise not be carried out as efficiently, or carried out at all, in a natural environment. Thus, university buildings create a condition and an atmosphere that is comfortable, healthy, and allows building users' potential to develop in an unconstrained way.

\section{Methodology}

In order to achieve the purpose of this study, the present paper based its preliminary findings on a review of literature of a broader study that employed a rational perspective concerning factors that affected university building maintenance costs. Moreover, this paper was a preliminary source for the preparation of data collection tools. The findings from this study were significant in assisting the researcher propose new approaches to overcome maintenance cost problems of university buildings. The research method employed in this study was from a review of literature on building maintenance issues. Thus, the selection of literature on factors that affected university building maintenance costs was based on published articles from acknowledged journals over the past ten years. The journals ranged between 2007 and 2017.

\section{Finding and Discussion}

The review of relevant literature discovered five key factors that affected university building maintenance costs. The factors were (i) fund allocations by university management teams for maintenance departments (ii) user behaviours (iii) environmental factors (iv) university design complexities and (v) the quality of components and materials of university buildings.

\subsection{Fund Allocations Allocated by University Management Teams}

Decision making is crucial in maintenance work, as it has an implication on maintenance costs, particularly for university buildings. The economic downturn in the last few years has meant that fund allocations for the building maintenance of universities has been reduced. Insufficient fund allocations for building maintenance affects the maintenance performance of buildings. Therefore, fund allocations for the building maintenance of universities must be sufficient in order to ensure maintenance work runs smoothly. Moreover, it has been found that there is a tendency to use low quality materials for university building maintenance works, due to limited fund allocations [16]

Consequently, university stakeholders or institutions must be dedicated to provide sufficient fund allocations to maintenance departments of universities. The allocation of sufficient funds will ensure that maintenance work carried out will be successful and will provide a conducive and comfortable place for building users to conduct academic activities.

\subsection{User Behaviours}

The maintenance work of university buildings has always been the main focus as university buildings are places where building users carry out their day-to-day activities. Although in the beginning, university buildings are in good condition, building defects occur due to a failure or delay in reporting problems, a lack of awareness of building users and vandalism or non-responsible attitudes caused by building users $[16,4,17]$.

Hence, to overcome this issue, senior management should provide their full support to maintenance departments in order to educate building users with building maintenance knowledge and have an awareness campaign, to ensure that building users know their responsibilities towards the building, which in turn, will sustain the building condition.

\subsection{Environmental Factors}

Climate changes and weather are environmental factors that cannot be avoided by any buildings, this includes university buildings. Hence, an exposure to environmental factors will cause 
defects to buildings. Nevertheless, if building materials and components are properly selected, maintenance costs can be reduced, as different building materials and components react differently to climate changes and weather $[18,19,2]$. Therefore, determining the right selection of designs, materials and components for buildings based on environmental factors is very important in prolonging the age of buildings.

\subsection{University Design Complexity}

University building maintenance work becomes complex, if at the initial stage of a design, maintainability aspects are ignored or neglected by designers. The neglect results in buildings maintenance works in future becoming difficult to maintain and will involve a huge amount of money to sustain university buildings $[7,20]$. Therefore, designers are strongly recommended to have a detailed discussion with maintenance managers at the initial stage of a building design. The discussion can be advantageous to ensure buildings are well-built and wellmaintained in the future.

\subsection{Quality of Components and Materials}

[2] wrote that maintenance problems will occur when buildings are commissioned or operated, if university buildings were built using poor and unreliable materials in order to cut costs. Additionally, good quality components and materials can also fail to meet standards if they are used for the wrong purpose or in an unsuitable environment. Each material has unique characteristics and conditions that a designer must not ignore [2]. The proper selection of materials and components for university buildings may assist in reducing costs of maintenance. Furthermore, durable and industry proven components and materials should be taken into consideration and utilized to reduce the impact of future maintenance issues.

\section{Conclusion}

The above discussion demonstrates that university buildings are vital assets procured to perform specific functions required by building users. Nonetheless, several factors can and will affect how university buildings perform during their life of service. Therefore, the present paper explained the key factors that led to building university maintenance costs. Following this, approaches to resolve each factor was proposed in order to ensure university buildings remain in good condition and are maintained well. The proposed approaches were as follows:

- To provide sufficient fund allocations to maintenance departments of universities

- Full support from senior management to maintenance departments in order to educate building users about building maintenance knowledge and have an awareness campaign

- Determining the right selection of designs, materials and components for buildings based on environmental factors

- Having detailed discussions with maintenance managers at the initial stages of a building design

- Proper selection of materials and components

Maintenance costs are a part of a building's lifecycle. Maintenance costs cover the expenditure of maintenance work that are carried out to preserve a university building or its components. Maintenance work ensures a building functions well and is built according to specifications. The encouragement and participation of key participants such as stakeholders, maintenance department staff, building users and management teams, are vital to enhance the efficiency of maintenance management of university buildings.

\section{References}

[1] Cruzan, R (2009), Manager's guide to preventive building maintenance. CRC Press.

[2] Olanrewaju AL \& Abdul-Aziz AR (2014), Building maintenance processes and practices: The case of a fast-developing country. Springer Singapore Heidelberg New Yorl Dordrecht LondonAuthor, Title of the Book, Publisher, (200X), pp:XXX-YYY.

[3] Kim Wing AC, Mohammed AH \& Abdullah MN (2016), Factors for maintenance priority in Malaysian university. Sains Humanika, 8(4-3). https://doi.org/10.11113/sh.v8n4-3.1075.

[4] Sani SIA, Mohammed AH, Shukor FSA \& Misnan MS (2012). Improvement maintenance work through adopting a maintenance culture: Focused the determinant factor which influence maintenance culture. 3rd International Conference on Business and Economic Research (3rd ICBER 2012) Proceeding, (May), 22062217.

[5] Olanrewaju AL, Idrus A \& Faris KM (2011), Investigating building maintenance practices in Malaysia: a case study. Structural Survey, 29(5), 397-410. https://doi.org/10.1108/02630801111182420.

[6] Toyin SP \& Yusof N (2013), Student satisfaction with hostel facilities in Nigerian polytechnics. Journal of Facilities Management, 11(4), 306-322. https://doi.org/10.1108/JFM-082012-0041

[7] Olanrewaju AL (2012), Quantitative analysis of defects in university buildings: user perspective. Built Environment Project and Asset Management, 2(2), 167-181. https://doi.org/10.1108/20441241211280909.

[8] Lee, HHY \& Scott D (2009), Strategic and operational factors â€TM influence on the management of building maintenance operation processes in sports and leisure facilities, Hong Kong. Journal of Retail \& Leisure Property, 8(1), 25-37. https://doi.org/10.1057/rlp.

[9] Abdallah M, El-Rayes K \& Liu L (2014), Optimal selection of sustainability measures to minimize building operational costs American Society of Civil Engineers, 2205-2213. https://doi.org/10.1061/9780784413517.0224.

[10] Krstić H \& Marenjak S (2017), Maintenance and operation costs model for university buildings. Technical Gazette, 24(1), 193-200. https://doi.org/10.17559/TV-20140606093626.

[11] Suffian A (2013), Some common maintenance problems and building defects: Our experiences. Procedia Engineering, 54, 101108. https://doi.org/10.1016/j.proeng.2013.03.009.

[12] Khalil N, Kamaruzzaman SN, Baharum MR \& Husin HN (2016), The performance-risk indicators (PRI) in building performance rating tool for higher education buildings. Journal of Facilities Management, 14(1), 36-49. https://doi.org/10.1108/JFM-03-20150009.

[13] Blessing O, Richard J \& Emmanuel A (2015), Assessment of building maintenance management practices of higher education institutions in Niger State - Nigeria. Journal of Design and Built Environment, 15(2), 1-14.

[14] Chan K (2012), Improving building safety in property maintenance. Property Management, 30(5), 465-476. https://doi.org/10.1108/02637471211273428.

[15] Falorca J, Calejo RR, \& Mendes dSR (2014), Research measurement of knowledge advances in building maintenance issues. Structural Survey, 32(1), 61-71. https://doi.org/10.1108/SS08-2012-0023

[16] Ali A, Kamaruzzaman S, Sulaiman R \& Cheong PY (2010), Factors affecting housing maintenance cost in Malaysia. Journal of Facilities Management, 8(4), 285-298. https://doi.org/10.1108/14725961011078990

[17] Kportufe GS (2015), Lack of maintenance culture of public buildings in the capital city of Ghana-Accra. Journal of Culture, Society and Development, 12, 94-103. Retrieved from www.iiste.org.

[18] Idrus A, Khamidi F \& Sodangi M (2010), Maintenance management framework for conservation of heritage buildings in Malaysia. Modern Applied Science, 4(11), 66-77.

[19] De Silva, N, Ranasinghe M \& De Silva CR (2012), Risk factors affecting building maintenance under tropical conditions. Journal of Financial Management of Property and Construction, 17(3), 235252. https://doi.org/10.1108/13664381211274353.

[20] Puksīe I, Sc M, Geipele I \& Doec P (2017), Different approaches to building management and maintenance meaning explanation. In Procedia Engineering (pp. https://doi.org/10.1016/j.proeng.2017.02.099. 